\title{
METHYL GREEN
}

\section{Reaction with Desoxyribonucleic Acid, Stoichtometry, AND Beravior of the Reaction Product*}

\section{BY N. B. KURNICK AND MARIIEE FOSTER}

\author{
(From the Department of Medicine, Tulane University School of Medicine, \\ New Orleans)
}

(Received for publication, June 12, 1950)

In previous publications, we have reported upon the basis of selective staining of nucleic acids by methyl green and pyronin $(1,2)$, upon the stoichiometry of the reaction (3), and upon the application of these observations to the quantitative histochemical estimation of polymerized desoxyribonucleic acid (4). It was found that methyl green is selective for highly polymerized desoxyribonucleic acids, whereas pyronin stains depolymerized desoxyribonucleic acid and ribonucleic acid (the latter believed to exist as low polymers only). Stoichiometric analysis (to which methyl green lends itself readily) showed that the compound formed with highly polymerized desoxyribonucleic acid (DNA) consisted of one dye molecule per ten phosphorus atoms. A number of observations $(2,3)$ based on dialysis experiments, lanthanum competition, and effect of increments of nucleic acid in excess of the stoichiometric amount on the absorption spectrum, indicated that the reaction was probably reversible with the equilibrium favoring the combined state.

The methyl green used in the stoichiometric studies (3) was labelled "C. I. Number 684, certification Number NG 3," purchased from National Aniline Corporation. This compound is heptamethyl para-rosaniline, prepared by the methylation of crystal violet. It contains sufficient unmethylated crystal violet to give the commercial powder a definite purple color. However, this dye is no longer available and methyl green $C$. I. Number 685, certification Number NG 26, is now substituted for it by National Aniline Corporation. Formerly labelled "ethyl green," the new "methyl green," ethyl hexamethyl para-rosaniline, is prepared by the ethylation of crystal violet with ethyl bromide and differs, therefore, from the original methyl green by the substitution of an ethyl group for a methyl group and a bromide for one of the two chlorides of methyl green C. I. Number 684 . This dye is green in the dry state, but nevertheless contains an appreciable amount of crystal violet which must be removed

* This work was supported in part by the National Heart Institute, United States Public Health Service. 
by chloroform extraction (2). Methyl green Number 685, which has the same specificity for polymerized DNA as has Number 684 (3), was used in the development of the histochemical method (4). The data obtained earlier for the stoichiometry of methyl green Number 684, were used in the calculations for the quantitative histochemical application, and it was found necessary to use a molar extinction coefficient at $645 \mathrm{~m} \mu$ of 75,000 for the methyl green-nucleic acid compound instead of the experimental 100,000 , so that the calculations would check with chemical analyses for nucleic acid.

The purpose of this communication is to report some characteristics of the methyl green-nucleic acid compound (using, primarily, methyl green Number 685) which permit a simple approach to the problem of stoichiometry. New data on the nature of the compound are thus obtained which clarify the calculations used in the histochemical method, confirm the hypothesis that the compound is in equilibrium with its uncombined constituents, and open new applications of the dye in the study of desoxyribonucleic acid and desoxyribonuclease.

\section{EXPERIMENTAL}

The two samples of methyl green described above were dissolved in $0.2 \mathrm{M} \mathrm{pH} 4.2$ acetate buffer to make a 0.04 per cent solution of the commercial dye. (All concentrations given in per cent refer to commercial dye.) The solutions were extracted repeatedly with chloroform until the extracts were entirely free of color as observed visually. The resultant solutions were found to have maximum absorption at 632.5 $\mathrm{m} \mu$ as measured in a Beckman quartz spectrophotometer (the difference between 632.5 and 635 previously found (2) may be ascribed to the use of different instruments ${ }^{1}$ ). The extinction coefficients at $640 \mathrm{~m} \mu$ were 31.7 for number 685 and 34.0 for Number 684 . The perchlorate of Number 685 was prepared by adding $70 \mathrm{cc} .0 .1 \mathrm{M}$ $\mathrm{HClO}_{4}$ neutralized with $10 \mathrm{~N} \mathrm{NaOH}$ to $90 \mathrm{cc} .0 .25$ per cent solution of the dye in 0.1 M $\mathrm{pH} 4.2$ acetate buffer (chloroform-extracted). The precipitate was filtered off on a Buchner funnel, washed with 3 to 4 small portions of cold $\mathrm{H}_{2} \mathrm{O}$, dried at $110^{\circ} \mathrm{C}$. to constant weight. A 0.00026 per cent solution of Number 685 gave an extinction coefficient in a $10 \mathrm{~mm}$. cell of 0.319 at $632.5 \mathrm{~m} \mu$ (maximum) and a 0.000428 per cent solution gave an $E$ of 0.533 . These correspond to molar extinction coefficients at 632.5 $\mathrm{m} \mu$ of 73,200 and 74,400 which closely approximate the value of 74,400 found for Number 684 ( $c f$. reference 2). At $640 \mathrm{~m} \mu$ the molar extinction coefficient is 70,800 . Thus, the commercial dyes were 60.7 per cent and 53.2 per cent pure for Number 685 and Number 684 respectively.

${ }^{1}$ The instrument used in the earlier experiments was calibrated with a mercury line source. However, the present instrument could be calibrated only with the hydrogen line as described in the Beckman Bulletin 89-B (Beckman Quartz Spectrophotometer, Instructions for Use of U.V. Accessories, National Technical Laboratories, South Pasadena, 1949, 3), and the mercury vapor absorption line at $253.7 \mathrm{~m} \mu$ (weak). 
As with Number 684 (Text-fig. 3 in reference 3) increments of polymerized sodium desoxyribonucleate (DNA) ${ }^{2}(5)$ were found to increase the extinction coefficient and shift the absorption maximum until a stable state was reached corresponding to a molar extinction coefficient at the maximum, $642.5 \mathrm{~m} \mu$ (compare again, $645 \mathrm{~m} \mu$ found with the instrument used in earlier experiments), of 100,700 and at $640 \mathrm{~m} \mu$ of 99,500 (average from Table I of values, within 2 per cent of the mean value, considered within limit of error of instrument).

To 5.0 cc. 0.001 per cent methyl green Number 685 in $0.008 \mathrm{M} \mathrm{pH} 4.2$ acetate buffer, increments of DNA $(28.4 \gamma \mathrm{P} / \mathrm{cc}$.) were added and the mixtures diluted to $9.0 \mathrm{cc}$. with $\mathrm{H}_{2} \mathrm{O}$. The results are given in Table $\mathrm{I}$.

TABLE I

\begin{tabular}{|c|c|c|c|c|c|c|}
\hline Experiment & $\mathbf{P}_{\text {DNA }}$ added & P/dye, molar & $E_{\text {mo }}$ & 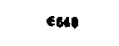 & $E_{\text {Mer, }}$ & CMR.8 \\
\hline & cc. $28.4 \gamma / c c$. & & & & & \\
\hline & 0 & 0 & 0.440 & 70,800 & 0.420 & 67,500 \\
\hline A & 0.25 & 3.82 & 0.437 & 70,500 & 0.430 & 69,350 \\
\hline B & 0.50 & 7.65 & 0.475 & 76,400 & 0.483 & 77,600 \\
\hline C & 0.75 & 11.46 & 0.532 & 85,500 & 0.544 & 87,400 \\
\hline D & 1.00 & 15.3 & 0.562 & 90,400 & 0.579 & 93,000 \\
\hline $\mathbf{E}$ & 1.25 & 19.1 & 0.574 & 92,400 & 0.581 & 93,500 \\
\hline F & 1.50 & 22.9 & 0.586 & 94,200 & 0.590 & 94,900 \\
\hline $\mathbf{G}$ & 2.0 & 30.6 & 0.605 & 97,300 & 0.613 & 98,500 \\
\hline $\mathbf{H}$ & 2.5 & 38.2 & 0.613 & 98,600 & 0.622 & 100,000 \\
\hline$I$ & 3.0 & 45.9 & 0.621 & 99,700 & 0.629 & 101,200 \\
\hline $\mathrm{J}$ & 3.5 & 53.6 & 0.622 & 100,000 & 0.627 & 100,850 \\
\hline $\mathbf{K}$ & 4.0 & 61.2 & 0.618 & 99,400 & 0.625 & 100,800 \\
\hline $\mathbf{L}$ & 5.0 & 76.4 & 0.630 & 101,700 & 0.636 & 102,900 \\
\hline
\end{tabular}

As with Number 684 , the stable state corresponded to mixtures with $\mathrm{P} /$ dye ratios in excess of 30 . The molar extinction coefficient of 100,700 at $642.5 \mathrm{~m} \mu$ agrees with that found for Number $684(2,3)$.

Methyl green Number 685 like Number 684 fades markedly at pH's outside the range 3.5-5.0. The fading proceeds fairly rapidly at $\mathrm{pH} 7.5$ and the color intensity becomes stable within 19 hours at room temperature. At $4^{\circ} \mathrm{C}$. fading is very slow and at $56^{\circ} \mathrm{C}$. equilibrium is attained in an hour (but DNA is rapidly depolymerized at this temperature). The $\mathrm{pH}$ was adjusted by adding to $5 \mathrm{cc}$. of solutions of the various concentrations of methyl green in $0.01 \mathrm{M} \mathrm{pH} 4.2$ acetate buffer, $0.524 \mathrm{cc} .0 .1 \mathrm{M}$ sodium veronal. As indicated in Table II, methyl

${ }^{2}$ Our thanks are due Dr. A. E. Mirsky of The Rockefeller Institute for Medical Research, who generously supplied us with a sample of DNA prepared in his laboratory for comparison to a sample prepared by us according to his method (5). The reactions with methyl green were identical for these two samples. 
green Number 685 at $\mathrm{pH} 7.5$ fades to 2.3 per cent of its extinction at $\mathrm{pH} 4.2$, and Number 684 to 2.0 per cent. This fading is reversible, and the original color

TABLE II

\begin{tabular}{|c|c|c|}
\hline$E_{640}^{\mathrm{pH}} 4.2$ & $E{ }_{640}^{\mathrm{pH}} 7.5^{*}$ & $E_{640}^{\mathrm{pH} 7.5} / E_{640}^{\mathrm{pH} 4.2}$ \\
\hline \multicolumn{3}{|c|}{ A. Fading of methyl green C. I. No. 685} \\
\hline 0.660 & 0.020 & $0.038 \ddagger$ \\
\hline 0.660 & 0.011 & 0.016 \\
\hline 0.660 & 0.017 & 0.026 \\
\hline 1.10 & 0.040 & $0.036 \ddagger$ \\
\hline 4.40 & 0.105 & 0.024 \\
\hline 4.40 & 0.110 & 0.025 \\
\hline 6.60 & 0.150 & 0.023 \\
\hline 8.80 & 0.190 & 0.022 \\
\hline 8.80 & 0.175 & 0.020 \\
\hline 8.80 & 0.192 & 0.022 \\
\hline 26.40 & 0.581 & 0.022 \\
\hline 26.40 & 0.626 & 0.024 \\
\hline 26.40 & 0.612 & 0.023 \\
\hline \multicolumn{2}{|c|}{ Average.$\ldots \ldots \ldots \ldots \ldots \ldots \ldots \ldots \ldots \ldots \ldots}$, & 0.023 \\
\hline \multicolumn{3}{|c|}{ B. Fading of methyl green, C. I. No. 684} \\
\hline 0.272 & 0.006 & 0.021 \\
\hline 0.850 & 0.014 & 0.017 \\
\hline 1.70 & 0.038 & 0.022 \\
\hline 2.26 & 0.046 & 0.021 \\
\hline 5.67 & 0.108 & 0.019 \\
\hline 11.33 & 0.221 & 0.020 \\
\hline 11.33 & 0.202 & 0.018 \\
\hline 11.33 & 0.214 & 0.019 \\
\hline 17.00 & 0.290 & 0.017 \\
\hline 17.00 & 0.329 & 0.019 \\
\hline 23.80 & 0.464 & 0.020 \\
\hline 23.80 & 0.459 & 0.019 \\
\hline 34.00 & 0.735 & 0.022 \\
\hline 34.00 & 0.722 & 0.021 \\
\hline 34.00 & 0.744 & 0.022 \\
\hline 34.00 & 0.736 & 0.022 \\
\hline \multicolumn{2}{|c|}{ Average $\ldots \ldots \ldots \ldots \ldots \ldots \ldots \ldots \ldots \ldots \ldots \ldots$} & 0.020 . \\
\hline
\end{tabular}

* These values corrected for dilution due to addition of sodium veronal.

$¥$ These values were not averaged because $E_{640}^{\mathrm{pH} 7.5}$ was too low for accurate measurement.

intensity is regained by adjusting the $\mathrm{pH}$ to 4.2 by the addition of one-tenth volume of $0.2 \mathrm{M} \mathrm{pH} 4.2$ acetate buffer. 
Solutions containing considerable excesses of DNA in proportion to methyl green, such that all the methyl green may be expected to be combined, do not fade upon the adjustment of the $\mathrm{pH}$ to 7.5. As the excess of DNA is reduced, so that the methyl green is not completely bound to DNA, progressive fading is observed (Table III).

Increments of DNA in $\mathrm{H}_{8} \mathrm{O}$ were added to $5.0 \mathrm{cc} .0 .001$ per cent methyl green Number 685 in $0.008 \mathrm{M} \mathrm{pH} 4.2$ acetate buffer to a final volume of $9.0 \mathrm{cc}$.

After 1 to 2 hours (this precaution was later found to be unnecessary since the reaction between DNA and methyl green proceeds as well at $\mathrm{pH} 7.5) 0.42 \mathrm{cc}$. $0.1 \mathrm{~m}$ sodium veronal was added to each of the above mixtures to adjust the $\mathrm{pH}$ to 7.5 . The tubes were stoppered and allowed to stand for 19 hours at room temperature and the

TABLE III

\begin{tabular}{c|c|c}
\hline P/dye, molar & $E_{640}^{\mathrm{pH} 4.2}$ & $B_{640}^{\mathrm{pH}} 7.5^{*}$ \\
\hline 76.4 & 0.630 & 0.630 \\
61.2 & 0.618 & 0.618 \\
53.6 & 0.622 & 0.619 \\
45.9 & 0.621 & 0.604 \\
38.2 & 0.613 & 0.602 \\
30.6 & 0.605 & 0.599 \\
22.9 & 0.586 & 0.539 \\
19.1 & 0.574 & 0.514 \\
15.3 & 0.562 & 0.503 \\
11.5 & 0.532 & 0.387 \\
7.7 & 0.475 & 0.299 \\
3.8 & 0.437 & 0.121 \\
\hline
\end{tabular}

* These values were corrected for dilution with sodium veronal.

Each experiment represents the average of several experiments.

extinction coefficients measured in the Beckman spectrophotometer at $640 \mathrm{~m} \mu$. The results are given in Table III.

It appears, therefore, that the methyl green-polymerized DNA compound unlike free methyl green, does not fade at $\mathrm{pH}$ 7.5.Increasing the $\mathrm{pH}$ up to 8.0 produces no appreciable effect on the extinction coefficient of the compound, but above this $\mathrm{pH}$, the compound fades (rapidly above 8.2).

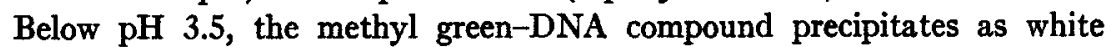
fibers.

Depolymerized DNA (prepared from solutions of polymerized DNA by heating in a boiling water bath or by subjection to the action of desoxyribonuclease) does not protect methyl green against fading at $\mathrm{pH}$ 7.5. This would be expected from the failure of methyl green to combine with depolymerized DNA. Depolymerization of the DNA by boiling or by enzyme action after the 
polymerized DNA-methyl green mixture has been permitted to fade to constant extinction (i.e., unbound methyl green has been allowed to fade out leaving essentially only combined methyl green to give the color), results in the fading characteristic of free methyl green. The action of boiling on methyl green itself is presumed not to be responsible for the observed fading since boiling free methyl green at $\mathrm{pH} 4.2$ results in no fading, while boiling methyl green-DNA at $\mathrm{pH} 4.2$ results only in shifting the absorption maximum back to $632.5 \mathrm{~m} \mu$ and reducing the extinction corresponding to that expected for

TABLE TV

\begin{tabular}{|c|c|c|c|c|c|c|c|c|}
\hline $\begin{array}{c}\text { Exper- } \\
\text { iment }\end{array}$ & $\begin{array}{c}\text { Volume of } \\
\text { mixture }\end{array}$ & $\underset{\mathrm{P}_{\mathrm{DNA}}^{-\mathbf{3}}}{\mathbf{M o l s}} \times$ & $\begin{array}{c}\text { Mols } \\
\text { Dye } \times 10-7\end{array}$ & P/dye & $\begin{array}{l}E_{640}^{\mathrm{pH}} 4.2 * \\
\text { Dye alone }\end{array}$ & $\begin{array}{l}E \mathrm{pH} 7.5^{*} \\
\text { Dye alone }\end{array}$ & $\begin{array}{l}\text { Dye }+ \\
\text { DNA } \\
E_{640} \mathrm{pH}^{*}\end{array}$ & $\begin{array}{l}\text { Compare } \\
E_{640} \mathrm{pH} .5 \\
\text { of fading } \\
\text { experiment } \\
\text { (Table V) }\end{array}$ \\
\hline \multicolumn{9}{|c|}{ Methyl green, C. I. No. 685} \\
\hline 1 & 9 & 458 & 5.75 & 79.65 & 0.452 & 0.009 & 0.644 & 0.634 \\
\hline $1 a$ & 9 & 458 & 5.75 & 79.65 & 0.452 & 0.009 & 0.630 & \\
\hline 10 & 9 & 91.6 & 18.6 & 4.93 & 1.46 & 0.029 & 0.670 & 0.684 \\
\hline $10 a$ & 9 & 91.6 & 18.6 & 4.93 & 1.46 & 0.029 & 0.671 & \\
\hline 12 & 6 & 22.9 & 37.5 & 0.61 & 4.42 & 0.087 & 0.386 & 0.381 \\
\hline $12 a$ & 6 & 22.9 & 37.5 & 0.61 & 4.42 & 0.087 & 0.386 & \\
\hline \multicolumn{9}{|c|}{ Methyl green, C. I. No. 684} \\
\hline 1 & 9 & 458 & 5.99 & 76.5 & 0.476 & 0.009 & 0.597 & 0.631 \\
\hline $1 a$ & 9 & 458 & 5.99 & 76.5 & 0.476 & 0.009 & 0.600 & \\
\hline 10 & 9 & 91.6 & 20.2 & 4.54 & 1.59 & 0.030 & 0.698 & 0.682 \\
\hline $10 a$ & 9 & 91.6 & 20.2 & 4.54 & 1.59 & 0.030 & 0.645 & \\
\hline 12 & 6 & 22.9 & 40.0 & 0.57 & 4.71 & 0.089 & 0.394 & 0.359 \\
\hline $12 a$ & 6 & 22.9 & 40.0 & 0.57 & 4.71 & 0.089 & 0.394 & \\
\hline
\end{tabular}

* Corrected to volume in column (2) which, as in Table V, corresponds to that of the methyl green-DNA without veronal.

free methyl green as compared to combined (2). Furthermore, depolymerization by desoxyribonuclease at room temperature results in the same changes, so that one may conclude that the alterations observed are due to the depolymerization of DNA with the consequent release of free methyl green which fades at $\mathrm{pH}$ 7.5.

Since the methyl green-DNA compound reveals maximum intensity of ab-

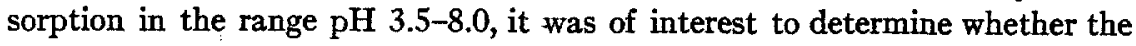
addition of DNA to free methyl green which had been allowed to fade at $\mathrm{pH}$ 7.5 would result in return of color intensity.

0.0133 per cent solutions of methyl green Number 685 and Number 684 in 0.01 M $\mathrm{pH} 4.2$ acetate buffer were adjusted to $\mathrm{pH} 7.5$ by the addition of 0.1 y sodium veronal 
( $0.524 \mathrm{cc}$. per $5.0 \mathrm{cc}$. methyl green). These were permitted to fade to stable extinction (19 hours). Appropriate dilutions were made with $0.01 \mathrm{M} \mathrm{pH} 7.5$ acetate-veronal buffer $(0.524$ cc. 0.1 м sodium veronal +5 cc. 0.01 м pH 4.2 acetate buffer.)

$\therefore$ To these solutions of faded methyl green various amounts of DNA were added as shown in Table IV. These experiments were set up to be comparable to those of Table $\mathrm{V}$ in which mixtures of DNA and colored dye $(\mathrm{pH} 4.2)$ were made and then allowed to fade upon adjusting the $\mathrm{pH}$ to 7.5. (Experiment designations are the same as in the corresponding experiments of Table V.) The extinctions were measured at 640 $\mathrm{m} \mu$ after equilibrium had been reached ( 99 hours).

It may be noted that for point 1 Number 685, where DNA is in great excess, complete recolorization of dye occurs

$$
\text { (i.e., } E_{640}^{\mathrm{pH4.2}} \text { dye } \times \frac{\epsilon_{640} \text { dye-DNA }}{\epsilon_{640} \mathrm{dye}}=0.452 \times \frac{99,500}{70,800}=0.637 .
$$

$C f .0 .644$ and 0.630 found). Thus "leuco methyl green" regains its color upon combination with polymerized DNA. Depolymerized DNA (prepared by the action of desoxyribonuclease or boiling) does not cause the color to return.

Methyl green Number 685, like methyl green Number 684, fades rapidly in the presence of alcohol. This is true also for the methyl green-DNA compound. Thus, the addition of an equal volume of 95 per cent ethyl alcohol to solutions of methyl green at $\mathrm{pH} 4.2$ or methyl green-DNA mixtures at $\mathrm{pH} 4.2$ or 7.5 results in rapid, complete fading.

$3.0 \mathrm{cc}$. of methyl green-DNA mixtures were allowed to stand 19 hours after adjustment to $\mathrm{pH} 7.5$, added to $12.0 \mathrm{cc}$. 95 per cent alcohol $+0.5 \mathrm{cc} .2 \mathrm{~m} \mathrm{NaCl}$, allowed to stand at $2^{\circ} \mathrm{C}$. for 18 hours, and centrifuged. In each case, the $E_{845}$ was 0 for the supernates. The white sediments were allowed to drain dry, dissolved in $3.0 \mathrm{cc} .0 .1 \mathrm{M}$ acetate buffer $\mathrm{pH}$ 7.5. Cloudy, colorless suspensions resulted.

Acetone appears to be without influence on the color intensity of methyl green at $\mathrm{pH} 4.2$ and of methyl green-DNA at $\mathrm{pH} 4.2$ or $\mathrm{pH} 7.5$. It may, therefore, be a suitable dehydrating agent in lieu of alcohol as previously suggested (4).

To $2.0 \mathrm{cc}$. of a methyl green-DNA mixture corresponding to $\mathrm{B}$ of Table $\mathrm{I}(\mathrm{P} /$ dye $=7.65$ ) were added $2.0 \mathrm{cc}$. acetone. Green fibers precipitated, leaving a very pale green supernate. These fibers were dipped in Sørensen's pH 7.5 phosphate buffer and then allowed to remain 1 week in $10.0 \mathrm{cc}$. acetone to which had been added $0.5 \mathrm{cc}$. pH 7.5 buffer. The green fibers retained their color apparently unimpaired.

Since the color of methyl green when combined with polymerized DNA is stable at $\mathrm{pH} 7.5$, whereas the free methyl green fades at this $\mathrm{pH}$, another method ( $c f$. references 2 and 3 ) was possible for analyzing the stoichiometry of the reaction. A number of mixtures were prepared with varying DNA to methyl green ratios at $\mathrm{pH} 4.2$. These were adjusted to $\mathrm{pH} 7.5$ with sodium veronal and allowed to fade to constant intensity ( 19 hours). From the extinction coefficients 
of these solutions at $640 \mathrm{~m} \mu$ it is possible to compute the number of mols of methyl green which have combined with DNA. Text-figs. 1 and 2 show the number of mols of methyl green Number 685, which have combined with 10.0 mols $P_{D_{N A}}$ (ordinates), plotted against the number of mols of methyl green originally added to 10.0 mols $P_{D N A}$ (abscissa; $\log$ scale in Text-fig. 2). Table $V$ lists the data (several experiments are averaged for each point) and calculations for both Nos. 685 and 684 . The method of calculation is given below:

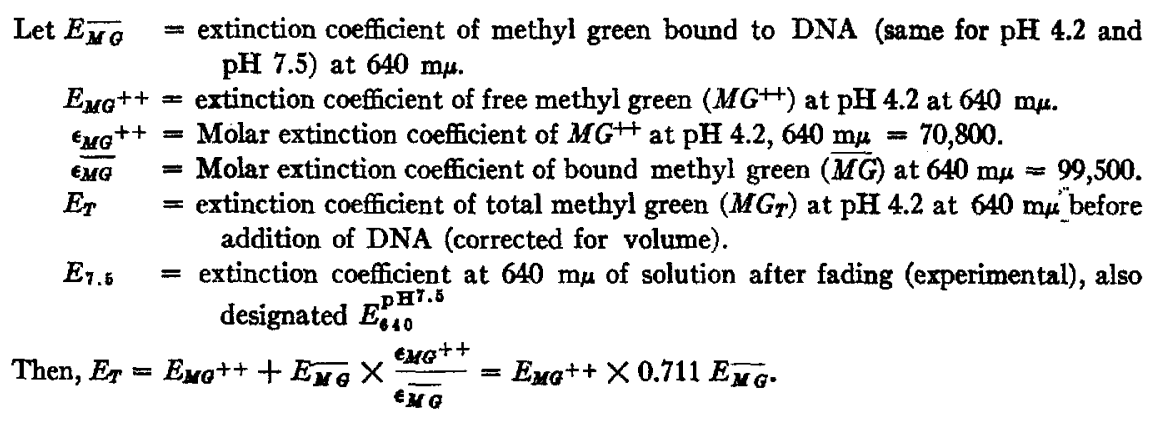

Therefore $E_{\boldsymbol{M G}}{ }^{++}=E_{T}-0.711 E_{\boldsymbol{M Q}}$

For No. 685: $E_{7.6}=E_{\overline{M Q}}+0.023 E_{M Q^{++}}$.

Therefore $E_{\eta, b}=E_{\overline{M G}}+0.023\left(E_{T}-0.711 E_{M \sigma}\right)$

$$
=E_{M G}+0.023 E_{T}-0.0163 E_{M G} \text {. }
$$

Therefore

$$
E_{M G}=\frac{E_{7.5}-0.023 E_{T}}{0.984} .
$$

For Number 684: $E_{7.6}=E_{M G}+0.020 E_{M G^{++}}$.

Therefore

$$
\begin{gathered}
E_{M \theta}=\frac{E_{7.6}-0.020 E_{T}}{0.986} . \\
\overline{M G}=\frac{E_{M Q} \times \text { volume in liters }}{99,500} \text { (in mols). } \\
M G^{++}=\frac{E_{M G^{++}} \times \text {volume in liters }}{70,000} \text { (in mols). } \\
M G_{T}=\overline{M G}+M G^{++} .
\end{gathered}
$$

Assuming that point 14 (Table V) is near enough the asymptote to warrant its use for the calculation of the stoichiometry of the reaction, we obtain $\mathrm{P} /$ dye $=13.6$ for Number 685 and $P /$ dye $=12.8$ for Number 684 . These values may be slightly too high since the asymptote may not have been quite attained. 
If the reaction of polymerized DNA with methyl green is an equilibrium reaction, the law of mass action gives us an equation of the type:

$$
\frac{\left[\mathrm{P}^{-}\right]^{2}\left[M G^{++}\right]}{[\overline{M G}]}=K
$$

TABLE V

\begin{tabular}{|c|c|c|c|c|c|c|c|c|c|}
\hline$\underset{\text { ment }}{\text { Experi- }}$ & $\begin{array}{l}\text { Volume of } \\
\text { mixture } \\
\text { before } \\
\text { addition } \\
\text { of veronal }\end{array}$ & $\underset{10^{-8}}{\mathrm{P}_{\mathrm{DNA}}^{\text {Mols }}} \times$ & dye Xis & $\mathrm{P} /$ dye & $\begin{array}{c}\text { Mols } M G_{T} \\
\text { per } 10 \text { mols } \\
\text { PDNA } \\
\left(M G_{T} / \mathrm{P} \times\right. \\
\left.10^{-1}\right) \text { in } \\
\text { original } \\
\text { mixture }\end{array}$ & $E_{T}$ & $E_{640}^{\mathrm{pH}} 7.5$ & $E_{\overline{M G}}$ & $\mid \begin{array}{c}\text { Mols } \overline{M G} \\
\text { per 10 mols } \\
\text { P DNA }_{\text {DNA }}^{(\overline{M G} / \mathbf{P}} \times \\
\left.10^{-1}\right)\end{array}$ \\
\hline
\end{tabular}

Methyl green, C. I. No. 685

\begin{tabular}{r|l|r|r|r|r|r|r|r|r}
\hline 1 & 9 & 458.0 & 5.60 & 81.80 & 0.122 & 0.44 & 0.634 & 0.634 & 0.125 \\
2 & 9 & 366.4 & 5.60 & 65.40 & 0.153 & 0.44 & 0.610 & 0.610 & 0.150 \\
3 & 9 & 274.8 & 5.60 & 48.90 & 0.204 & 0.44 & 0.605 & 0.605 & 0.199 \\
4 & 9 & 229.0 & 5.60 & 40.90 & 0.244 & 0.44 & 0.602 & 0.602 & 0.238 \\
5 & 9 & 137.4 & 5.60 & 24.55 & 0.407 & 0.44 & 0.550 & 0.549 & 0.361 \\
6 & 9 & 114.5 & 5.60 & 20.45 & 0.490 & 0.44 & 0.515 & 0.514 & 0.406 \\
7 & 9 & 91.6 & 5.60 & 16.35 & 0.611 & 0.44 & 0.467 & 0.465 & 0.461 \\
8 & 9 & 68.7 & 5.60 & 12.27 & 0.815 & 0.44 & 0.388 & 0.384 & 0.505 \\
9 & 9 & 45.8 & 5.60 & 8.18 & 1.22 & 0.44 & 0.299 & 0.294 & 0.580 \\
10 & 9 & 91.6 & 20.50 & 4.47 & 2.25 & 1.61 & 0.684 & 0.659 & 0.653 \\
11 & 9 & 91.6 & 40.80 & 2.24 & 4.46 & 3.21 & 0.778 & 0.717 & 0.707 \\
12 & 6 & 22.9 & 40.80 & 0.56 & 17.8 & 4.81 & 0.381 & 0.275 & 0.724 \\
13 & 6 & 22.9 & 81.60 & 0.28 & 35.7 & 9.61 & 0.496 & 0.279 & 0.734 \\
14 & 9 & 22.9 & 244.80 & 0.093 & 107.1 & 29.43 & 0.950 & 0.278 & 0.731 \\
\hline
\end{tabular}

Methyl green, C. I. No. 684

\begin{tabular}{r|r|r|r|r|r|r|r|r|r}
\hline 1 & 9 & 458.0 & 6.00 & 76.33 & 0.131 & 0.472 & 0.631 & 0.631 & 0.125 \\
10 & 9 & 91.6 & 20.00 & 4.08 & 2.18 & 1.575 & 0.682 & 0.660 & 0.651 \\
11 & 9 & 91.6 & 40.00 & 2.04 & 4.36 & 3.15 & 0.769 & 0.717 & 0.707 \\
12 & 6 & 22.9 & 40.00 & 0.51 & 17.4 & 4.72 & 0.359 & 0.269 & 0.708 \\
13 & 6 & 22.9 & 80.00 & 0.26 & 34.8 & 9.44 & 0.456 & 0.271 & 0.713 \\
14 & 6 & 22.9 & 240.00 & 0.087 & 104.4 & 28.30 & 0.860 & 0.298 & 0.785 \\
\hline
\end{tabular}

assuming that the combination involves two phosphoric groups $(\mathrm{P})$ per methyl green $(2)$ and letting $\left[\mathrm{P}^{-}\right]$represent the effective concentration of uncombined $\mathrm{P}$ (i.e., approximately 1 uncombined $\mathrm{P}$ in 6 ).

It follows that simple dilution will shift the equilibrium, favoring dissociation in order to maintain $K$ constant. In order to test this prediction, mixtures of DNA and methyl green which had been permitted to come to equilibrium at $\mathrm{pH} 7.5$ were diluted with $0.01 \mathrm{M} \mathrm{pH} 7.5$ acetate-veronal buffer and allowed to 


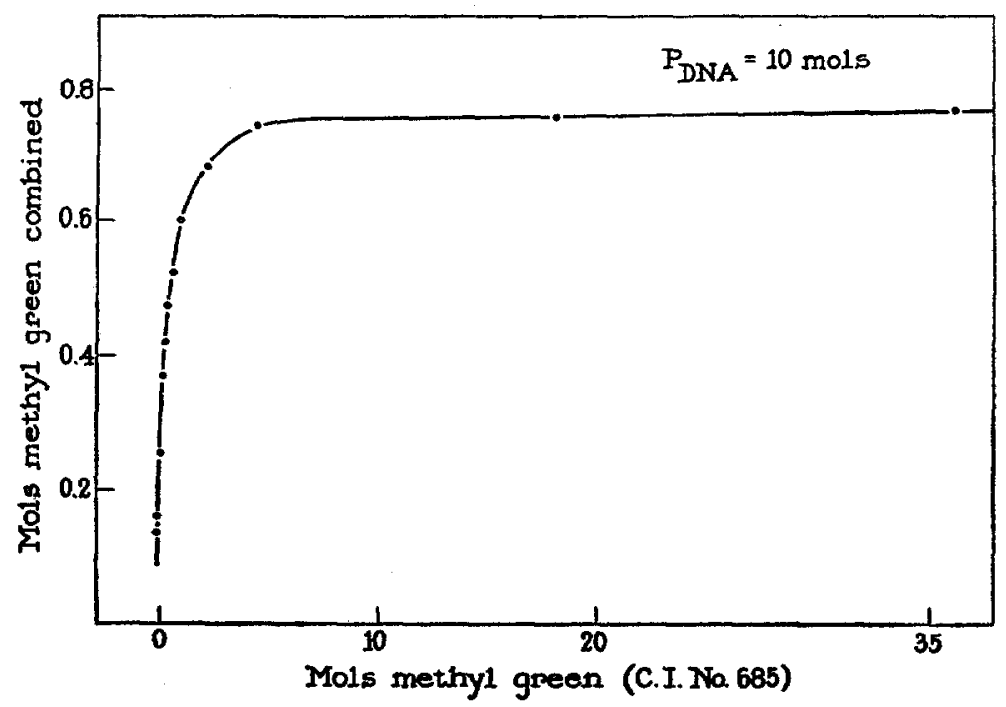

Texr-Fig. 1. Mols methyl green combined per 10 mols DNA phosphorus (ordinates) plotted against mols methyl green mixed with 10 mols DNA phosphorus (abscissa).

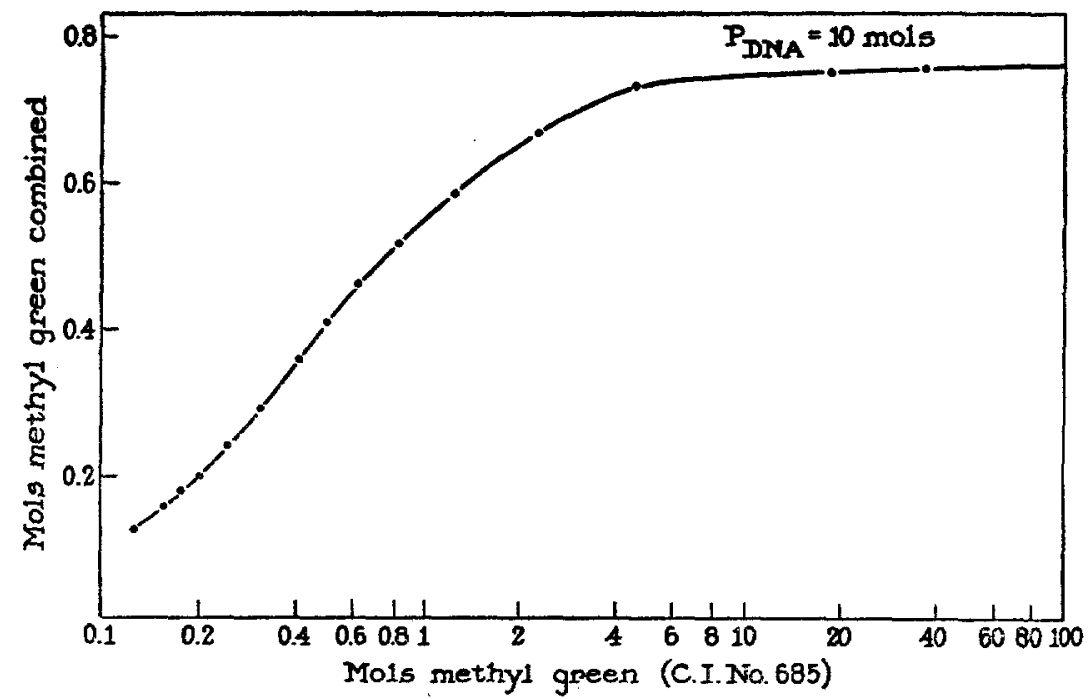

Text-Fig. 2. Same as Text-fig. 1 with abscissa plotted on logrithmic scale.

stand overnight at room temperature (about $25^{\circ} \mathrm{C}$.) to reach equilibrium. It was found that the diluted solutions became infected easily and, therefore, to prevent this, one drop of toluene was added to each solution. The extinc- 
tions were measured after equilibrium was attained. The results (Table VI) reveal that fading has, in fact, occurred.

TABLE VI

\begin{tabular}{|c|c|c|c|c|c|c|c|c|c|}
\hline Experiment & $\begin{array}{c}\text { Volume } \\
\text { of } \\
\text { mix- } \\
\text { ture }\end{array}$ & $\underset{\substack{\text { Pols } \\
\text { Pr }_{T}}}{\text { PNA }^{\text {Mols }}} \times$ & $\mid \begin{array}{c}\text { Mols } \\
\text { dye } \times 10^{-t} \\
\text { MG }\end{array}$ & $\underset{\text { dye }}{\text { P }_{\text {DNA }}}$ & ${ }^{E_{T}}$ & $E_{7.5}$ & $E_{\overline{M G}}$ & $\begin{array}{c}\text { Expected } \\
E_{\text {MCG }} \\
\text { in absence } \\
\text { of } \\
\text { dissociation }\end{array}$ & $x$ \\
\hline \multicolumn{10}{|c|}{ Methyl green, C. I. No. 685} \\
\hline 2 & 6 & 183.2 & 3.0 & 61.67 & 0.354 & 0.398 & 0.397 & & \\
\hline 2 dil. 1:5 & 30 & 183.2 & 3.0 & 61.67 & 0.071 & 0.076 & 0.076 & 0.079 & \\
\hline 10 & 9 & 91.6 & 20.2 & 4.54 & 1.590 & 0.735 & 0.712 & & \\
\hline 10 dil. $1: 5$ & 45 & 91.6 & 20.2 & 4.54 & 0.318 & 0.103 & 0.098 & 0.142 & 12.9 \\
\hline & 9 & 91.6 & 20.2 & 4.54 & 1.575 & 0.719 & 0.694 & & \\
\hline $10^{\prime}$ dil. $1: 5$ & 45 & 91.6 & 20.2 & 4.54 & 0.315 & 0.101 & $0.096 \mid$ & 0.139 & 13.0 \\
\hline 11 & 9 & 91.6 & 40.4 & 2.27 & 3.150 & 0.819 & 0.760 & & \\
\hline 11 dil. $1: 5$ & 45 & 91.6 & 40.4 & 2.27 & 0.630 & 0.142 & 0.130 & 0.152 & 12.7 \\
\hline 13 & 6 & 22.9 & 80.7 & 0.28 & 9.540 & 0.480 & 0.270 & & \\
\hline 13 dil. $1: 5$ & 30 & 22.9 & 80.7 & 0.28 & 1.910 & 0.092 & 0.050 & 0.054 & \\
\hline \multicolumn{10}{|c|}{ Methyl green, C. I. No. 684} \\
\hline 1 & 9 & 458.0 & 6.0 & 76.33 & 0.472 & 0.634 & 0.634 & & \\
\hline 1 dil. $1: 5$ & 45 & 458.0 & 6.0 & 76.33 & 0.094 & 0.118 & 0.118 & 0.127 & \\
\hline 10 & 9 & 91.6 & 20.0 & 4.58 & 1.575 & 0.707 & 0.685 & & \\
\hline 10 dil. $1: 5$ & 45 & 91.6 & 20.0 & 4.58 & 0.315 & 0.105 & 0.096 & 0.137 & 13.0 \\
\hline 11 & 9 & 91.6 & 40.0 & 2.29 & 3.150 & 0.799 & 0.747 & & \\
\hline 11 dil. $1: 5$ & 45 & 91.6 & 40.0 & 2.29 & 0.630 & 0.130 & 0.120 & 0.149 & 12.8 \\
\hline 13 & 6 & 22.9 & 80.0 & 0.29 & 9.450 & 0.515 & 0.333 & & \\
\hline 13 dil. 1:5 & 30 & 22.9 & 80.0 & 0.29 & 1.890 & 0.107 & 0.070 & 0.067 & \\
\hline
\end{tabular}

* Original volume of mixture, before addition of veronal, on which all calculations are based.

By setting the equilibrium equations equal to each other, we can solve for the ratio of $\mathrm{P} /$ dye in the compound.

At $640 \mathrm{~m} \mu$,

$$
\begin{aligned}
{[\overline{M G}] } & =\frac{E \overline{M O}}{99,500} \\
{\left[M G^{++}\right] } & =\frac{E_{T}}{70,800}-[\overline{M G}] \\
{\left[\mathrm{P}^{-}\right] } & =\frac{\left[\mathrm{P}_{T}\right]-X[\overline{M G}]}{\frac{1}{2} X}
\end{aligned}
$$


where the symbols are the same as in the preceding formulae, $\left[\mathrm{P}_{T}\right]$ is the molar concentration of total DNA phosphorus added, and $X$ is the stoichiometric ratio $\mathrm{P} /$ dye.

Then, substituting the last three equations in the formula for $K$ above,

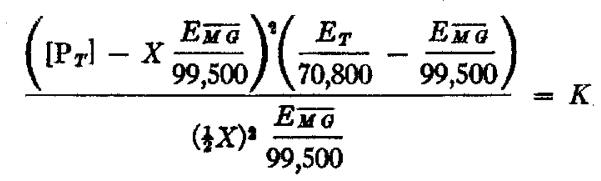

Setting $K$ for diluted and undiluted samples equal to each other, we solve for $X$ (Table VI). The value of $\mathrm{P} /$ dye of 12.9 thus found agrees with the values 12.8 and 13.6 obtained from Table $V$.

\section{DISCUSSION AND CONCLUSION}

The data permit certain conclusions in regard to the composition and behavior of the compound formed between DNA and methyl green. It appears that the reaction is an equilibrium state since excess of either constituent favors complete combination of the other. Furthermore, the compound appears to have the composition of $13 \mathrm{P} /$ dye ( 0.077 dye/P) for both Nos. 685 and 684 . This conclusion is based upon calculations from the mass law and upon the observation (Text-fig. 1) that large excesses of methyl green result in a compound of this constitution. Excesses of methyl green in the range of 3 to 1000 times give the same result. In view of the reversibility of the reaction, lesser excesses result in less complete binding of the DNA. Large excesses of DNA result in complete binding of methyl green. The value of $13 \mathrm{P} /$ dye for Number 685 accounts for the discrepancy between the $\epsilon_{645}$ of 100,000 found for the DNAmethyl green compound in vitro and that of 75,000 required in the formula for the quantitative estimation of polymerized DNA in nuclei (4). In these calculations a stoichiometric ratio of $10 \mathrm{P} /$ dye was assumed. The new ratio requires a factor of $13 / 100,000$ in converting the measured extinction coefficient to mols $\mathrm{P}$ instead of $10 / 75,000$. The result of the calculation is, obviously, uninfluenced, but it is gratifying to find that the $\epsilon_{645}$ is the same in vitro and in nucleo.

The observation that the reversible fading of methyl green on changing the $\mathrm{pH}$ from 4.2 to 7.5 does not occur for the methyl green-DNA compound is of interest. It has been presumed that this fading is due to the conversion of the quinonoid form of the dye to a benzenoid form with the formation of the carbinol. The combination with DNA apparently prevents this intramolecular rearrangement. The gradual reestablishment of the color of the "leuco" dye upon the addition of polymerized DNA suggests that the carbinol and quinonoid forms exist in equilibrium so that as the quinonoid form becomes combined with methyl green the carbinol is converted to the quinonoid to make more available. 
A number of applications of the phenomenon of the difference in behavior of free and combined methyl green at $\mathrm{pH} 7.5$ are under investigation. It is proposed that a quantitative histochemical application of "leuco dye" may present advantages in specificity and accuracy over the use of concentrated dye at $\mathrm{pH} 4.2$ followed by washing. Furthermore, since depolymerization of the DNA by desoxyribonuclease results in dissociation with consequent fading of the free dye at $\mathrm{pH} 7.5$ (near the optimum for nuclease activity $(6,7)$ ) a sensitive test for this enzyme has been devised which will be the subject of a separate communication (8).

Precautions in the avoidance of heat and alcohol (the former at all times, the latter in the presence of the stain or stained nucleic acid) are again (4) found to be necessary in the histochemical determination of polymerized DNA.

The previously observed phenomenon that an excess of DNA up to approximately twice stoichiometric results in further modification of the absorption spectrum of methyl green (3) is accounted for in the observation that complete combination of the methyl green does not occur until such an excess is available (Text-fig. 2, mols methyl green combined per $10 \mathrm{P}_{\mathrm{DNA}}$ equals total mols methyl green up to about $0.4 \mathrm{~mol}$, whereas stoichiometric is $0.77 \mathrm{~mol}$ ). This is in accord with the previously hypothesized equilibrium state (3). The equilibrium reaction is further demonstrated by the effect of simple dilution in increasing dissociation, from which the stoichiometric constant was calculated.

\section{SUMMARY}

1. Methyl green ("ethyl green") C. I. Number 685 was examined and found to behave identically with methyl green C. I. Number 684 (no longer available) in respect to molar extinction coefficient, effect of combination with polymerized DNA, failure to react with depolymerized DNA, and effect of $\mathrm{pH}$.

2. The mass law permits the calculation of $P /$ dye. This is found to be 13 $\mathrm{P} /$ dye. The same value is obtained when an excess of methyl green is caused to fade by adjusting the $\mathrm{pH}$ to 7.5 .

3. The compound formed by methyl green with DNA has the same maximum absorption at 642.5 to $645 \mathrm{~m} \mu$ in the $\mathrm{pH}$ range 3.5-7.8, whereas the free dye fades markedly above $\mathrm{pH}$ 5.0.

\section{REFERENCES}

1. Kurnick, N. B., Cold Spring Barbor Symp. Quant. Biol., 1947, $12,141$.

2. Kurnick, N. B., J. Gen. Physiol., 1950, 33, 243.

3. Kurnick, N. B., and Mirsky, A. E., J. Gen. Physiol., 1950, 33, 265.

4. Kurnick, N. B., Exp. Cell Research, 1950, 1, 151.

5. Mirsky, A. E., and Pollister, A. W., J. Gen. Physiol., 1946, 30, 117.

6. Kunitz, M., J. Gen. Physiol., 1950, 33, 363.

7. McCarty, M., J. Gen. Physiol., 1946, 29, 123.

8. Kurnick, N. B., Arch. Biochem., in press. 